\title{
THE EUROPEAN UNION AND NATURAL RESOURCES THAT FUND ARMED CONFLICTS: EXPLAINING THE EU'S POLICY CHOICE FOR SUPPLY CHAIN DUE DILIGENCE REQUIREMENTS 12
}

Martijn C. Vlaskamp (Marie Skłodowska-Curie Global Fellow at the Institut Barcelona d'Estudis Internacionals (IBEI) and the MacMillan Center for International and Area Studies at Yale), mvlaskamp@ibei.org

This is the accepted version of the paper. The published version is: Vlaskamp, M.C. (2018) "The European Union and natural resources that fund armed conflicts: Explaining the EU's policy choice for supply chain due-diligence requirements", Cooperation and Conflict, 1-19, () The Author 2018. DOI: $10.1177 / 0010836718808314$.

\begin{abstract}
:
Natural resources can be an important source of funding for warring parties in armed conflicts. Curbing the trade in these so-called conflict resources is, therefore, part of the European Union's (EU) conflict management policies. The article explores the EU's policies in this field and asks, specifically, why the EU is using supply chain due diligence measures to achieve this goal. The author argues they are the response to enforcement problems of most existing multilateral and unilateral sanction regimes because of state weakness in the targeted regions. This approach results from a broader idea from the EU that transparency can improve resource governance and, therefore, safeguard both its political and economic interests in conflict zones, such as the eastern Democratic Republic of the Congo. However, when the issue became specific - as in the EU Conflict Minerals Regulation-translating this idea into concrete policies became more contentious as the different actors set different priorities for the final policy design.
\end{abstract}

\footnotetext{
${ }^{1}$ Many thanks go to Esther Barbé Izuel, Hamish van der Ven and two very constructive and helpful anonymous reviewers for their feedback. A previous version of this paper was presented at the $57^{\text {th }}$ Annual Convention of the International Studies Association (ISA), March $16^{\text {th }}-19^{\text {th }}, 2016$ in Atlanta (GA). The usual attribution of possible faults applies. I would also like to thank the interviewees for their time, comments and clarifications. All interviews were conducted under Chatham House rules.

${ }^{2}$ This work was supported by the EU's Horizon 2020 research and innovation program [grant number 660245]; and the Spanish Ministry of Economy and Competiveness [grant number CSO2016-79205-P].
} 


\section{INTRODUCTION}

On April 3, 2017, the Council of the EU adopted the 'Conflict Minerals Regulation'. Almost seven years after the European Parliament had first called for a legislative initiative to deal with this issue, the EU member states agreed on supply chain due diligence requirements for gold, tin, tantalum, and tungsten ('3TG') importers. The declared aim of the regulation is to prevent the financing of armed groups and security forces in resource-rich areas through the illegal trade of natural resources. While the Conflict Minerals Regulation is not limited in geographical scope, it was primarily motivated by the situation in the eastern Democratic Republic of the Congo (DRC), where army and rebel groups fund themselves, at least partially, with minerals. By adopting this regulation, the EU hoped to 'provide transparency and certainty as regards the supply practices of Union importers, and of smelters and refiners sourcing from conflict-affected and high-risk areas' (Council of the EU, 2017b: 18).

Until this regulation, the EU's predominant approach to this issue had been to include specific commodities, extractive companies, or resource-related activities on its sanctions lists. Most of these measures are implementations of decisions in the United Nations Security Council (UNSC) or the Kimberley Process Certification Scheme (KPCS) for rough diamonds. The Conflict Minerals Regulation is the first EU policy exclusively dedicated to so-called conflict resources, which will be understood in this article as 'natural resources whose systematic exploitation and trade in a context of conflict contribute to, benefit from, or result in the commission of serious violations of human rights, violations of international humanitarian law, or violations amounting to crimes under international law' (Global Witness, 2006: 10). ${ }^{3}$

This paper aims to explain why the EU has chosen supply chain due diligence requirements as a tool to curtail trade in conflict resources. To borrow the Conflict Minerals Regulation's definition, supply chain due diligence can be understood as the obligations of importers of selected natural resources 'in relation to their management systems, risk management, independent third-party audits and disclosure of information with a view to identifying and addressing actual and potential risks linked to conflict-affected and high-risk areas to prevent or mitigate adverse impacts associated with their sourcing activities' (Council of the EU, 2017b: 20). By answering this question, the article will be one of the first studies of the EU's policies concerning conflict resources while contributing to the literature that discusses EU

\footnotetext{
${ }^{3}$ The EU Timber Regulation, which will be described in more detail below, also covered 'conflict timber', but was primarily motivated by environmental concerns.
} 
restrictive measures (Giumelli, 2011; Portela, 2005, 2011). The empirical part of this article is based on a review of primary and secondary literature, participation in practitioners' meetings, and 25 semistructured interviews with EU and national officials, industry spokespersons, and advocacy NGOs.

This article is structured as follows. In the second section, I will describe previous EU policies on conflict resources. In section 3, I will present a brief analytical framework to look at EU external policy choices. Following this framework, in section 4, I will discuss the EU's interests concerning the issue of conflict resources. In the fifth section, I will describe the ideational underpinnings that have brought EU policymakers to the idea that supply chain due diligence requirements are an effective tool to safeguard these interests. I will discuss in section 6 the policymaking process of the EU Conflict Minerals Regulation to illustrate how the different institutions came to the final policy output. In the final section, I will summarise the findings.

\section{PREVIOUS EU POLICIES AGAINST CONFLICT RESOURCES}

Before I discuss the Conflict Minerals Regulation further, I will first provide some background information about the EU policies against conflict resources that preceded this measure. The issue of conflict resources emerged in the mid-1990s, after the end of the Cold War and the role of diamonds in the civil wars in Angola, Sierra Leone, and the DRC drew much attention. In some conflicts, armed groups benefited from trading commodities directly while, in others, they imposed taxes, sold extraction permissions, or levied road tolls (Le Billon, 2012). One of the first mentions of conflict resources in EU policy documents can be found in the 2001 Gothenburg programme, which included the aim of tackling the 'illicit trade in high-value commodities' (European Council, 2001). Since then, the link between natural resources and armed conflicts has been routinely mentioned in EU conflict management documents. The 2003 European Security Strategy warned that the illegal trade of gemstones and timber could fuel conflicts and undermine the rule of law and social order (Council of the EU, 2003: 4). In the report about the strategy's implementation five years later, the 'ruthless exploitation' of natural resources was seen as an underlying cause of conflict that required multilateral solutions (Council of the EU, 2008: 8). At the 2013 UNSC Open Debate on Conflict Prevention and Natural Resources, the EU declared that 'natural resources play a critical role in fuelling and financing conflict' but was more cautious about seeing them as a root cause of conflict (UNSC, 2013: 32). In the 2016 Global Strategy for the EU's Foreign and Security Policy, a special section was devoted to the 'political economy of peace', which said that 'to fight 
the criminal war economy, the EU must also modernise its policy on export control for dual-use goods, and fight the illegal trafficking of cultural goods and natural resources' (European Union, 2016: 32).

Most of the EU's policy measures concerning conflict resources are sanctions regimes, which are downloaded from the UNSC and the KPCS, an import and export scheme for rough diamonds, which will be discussed in more detail below. As in most other cases of global security issues, the EU sees multilateral institutions, and, namely, the UN, as the first point of reference for measures (Manners, 2008). The Kimberley Process is integrated into the UN system and, each year, the UN General Assembly reaffirms its 'strong and continuing support for the Kimberley Process and its related certification scheme' (Smillie, 2014: 98). As in the cases of other sanctions regimes, the EU has also occasionally 'supplemented' UNSC resolutions, or even implemented unilateral sanctions if it deemed this in its interest (Biersteker and Portela, 2015). In 2007, after the violent oppression of anti-Government protests by the regime, the EU adopted sanctions on timber, gems, and metals from Myanmar (Jones, 2015: 108). Two years later, as a reaction to the electoral unrest in Zimbabwe, the EU put a ban on diamonds traded by the state-owned Zimbabwe Mining Development Corporation (Vlaskamp, 2013). During the 2011 civil war in Côte d'Ivoire, the EU went beyond UNSC Resolution 1975/2011 by also targeting the country's cocoa industry with sanctions, knowing this resource was a major income source of sitting President Laurent Gbagbo (Council of the EU, 2011). In Syria, the EU has, since 2012, unilaterally imposed sanctions against oil that may fund the Syrian Government ${ }^{4}$ (Council of the EU, 2012, 2013a).

So far, the EU has not opted for military steps to neutralise the effect of conflict resources (some member states, however, participated in the air strikes against Islamic State-controlled oil infrastructure in Syria). The initial objectives of EU NAVOR operations ATALANTA, off the Horn of Africa, and SOPHIA, in the Mediterranean, did not explicitly include implementing the UN sanctions against al-Shabaab's charcoal and oil, which fund armed groups in Libya (EU Official, 2015). However, in July 2017, the Council amended SOPHIA's mandate to allow it to 'conduct surveillance activities and gather information on illegal trafficking, including information on crude oil and other illegal exports that are contrary to UNSCR 2146 (2014) and UNSCR 2362 (2017)' (Council of the EU, 2017a).

\footnotetext{
${ }^{4}$ In 2013, an exception for 'moderate rebels' was added to the EU sanctions regimes. In 2015, the UNSC adopted sanctions against the oil trade with the Islamic State and the al Qaeda-linked Nusra Front.
} 


\section{ANALYTICAL FRAMEWORK}

To understand the choices for the EU Conflict Minerals Regulation, the text will follow Hyde-Price's framework, which proposes three pillars for EU foreign policy analysis: interests, identity, and institutions (Hyde-Price, 2004). These three pillars cannot be seen separately from each other but are interconnected. The first leg of Hyde-Price's conceptual framework is the EU's interests, referring to 'their preferences and concerns' (Hyde-Price, 2004: 102), concerning a specific issue. As the EU is not an ordinary state actor, the interests are often hard to define and involve the preferences of member states and EU institutions but also lobby groups and NGOs. ' 'European' interests can only be seen as the outcome of a discrete political process', as Hyde-Price argues (Hyde-Price, 2004: 102). For this article, the first part of the analysis will identify the different stakeholders' interests that motivated the change to supply chain due diligence requirements.

These interests can be material, e.g. economic and security concerns but can also be the result of immaterial normative considerations. This leads to the second leg of Hyde-Price's conceptual framework, which he calls 'identities' ${ }^{5}$. Several authors have argued that the EU is not simply the sum of its 28 member states but has its own international identity as a 'normative power' with shared principles, such as sustainable peace, freedom, democracy, human rights, rule of law, equality, social solidarity, sustainable development, and good governance (Manners, 2008: 46). This identity and discourse is, however, not static and clear-cut and there is a continuous discussion about 'what is legitimate and possible as an EU foreign policy' (Diez, 2014: 330). Occasionally, some of these norms collide and cause contradicting policy implications (Saltnes, 2017). At the same time, the road towards specific objectives can also be determined by shared ideas. As Keohane and Goldstein have argued, ideas can serve as (I) roadmaps to guide actors' preferences and how to get there, as (II) 'focal point' if there is no consensus, or (III) as 'causal beliefs' about how one cause leads to a certain (desired) effect (Goldstein and Keohane, 1993). Interests are, hence, not, as some rationalist scholars argue, completely objective preferences but influenced by an actor's identity and ideas. Therefore, the second part of the analysis will ask why the EU adopted supply chain due diligence measures as a policy to promote its interests, instead of other policy alternatives, such as sticking to its sanctions policies.

\footnotetext{
${ }^{5}$ Hyde-Price used another order (interest, institutions, identity) as his book chapter mainly wanted to show some limitations of neorealism.
} 
Finally, the third pillar of the analysis can be summarised under the term 'institutional factors' (HydePrice, 2004: 104ff). The EU's policymaking process can be very complex with numerous stakeholders involved. Krahmann describes the decision-making process as a multilevel network in which not only the EU institutions and member states are involved, but also parties, national parliaments, ministries, civil servants, etc. (Krahmann, 2003). These actors may have their own positions based on immaterial and material interests. The third part of the analytical framework is, therefore, to map these differences and, through process tracing, explain how the involved actors came to the final policy outcome.

\section{THE EU'S INTERESTS CONCERNING CONFLICT RESOURCES}

As so often in foreign policy analysis, there was not only one interest at stake, but a number of political and economic factors played a role (NGO Representative, 2013).

The first interest was politically motivated and related to the EU's conflict prevention or management policies, especially with an eye on the DRC. While the EU Conflict Minerals Regulation has no geographic limitation, it was made considering the situation in the DRC. The EU had spent a considerable amount of time and money on the DRC and 'more than any other international actor, the EU ha(d) been fervently active in forging peace in DRC through both civilian and military means' (Smis and Kingah, 2009: 222). The DRC has been the recipient of the largest numbers of EU Common Security and Defence Policy operations ${ }^{6}$ and is the primary beneficiary of EU development aid in sub-Saharan Africa (Arnould and Vlassenroot, 2016). Moreover, as Knutsen concluded, the Congo conflict was (and it still is) 'a laboratory for EU crisis management' (Knutsen, 2009: 456). This conflict has frequently been characterised as resource-driven and many policymakers and NGOs assumed that ending the trade in these conflict resources would also contribute to improving the DRC's security situation. An interviewed EEAS official remarked that it was part of the EU's comprehensive approach to 'first identify the cause of a problem and then to apply all the instruments at its disposal to tackle them' (EEAS Official, 2013). In the context of conflict resources, the idea was that cutting the financial benefits of this trade would make it less feasible and economically attractive to continue fighting for armed groups (Le Billon, 2012). Adopting a policy that would cut the funding of these armed groups was, therefore, by NGOs and pro-regulation Members

\footnotetext{
${ }^{6}$ ARTEMIS, EUFOR DR Congo, EUSEC DR Congo, EUPOL Kinshasa and EUPOL DR Congo.
} 
of the European Parliament (MEPs), seen as a way to promote the broader objective of improving the DRC's security situation.

A second factor that motivated the adoption of the EU Conflict Minerals Regulation was economic interests. Many people at the Commission and business actors saw this policy as part of a broader approach to the question of how the EU could guarantee its resource supply (Dutch Official, 2013). During that time, the fear of resource scarcity was very present in many EU member states and they, therefore, called on the Commission to find ways to guarantee a steady supply of raw materials (European Commission, 2008, 2011). As an interviewed diplomat said, stabilising the region was part of a strategy to "not let Africa's resources fall completely into the hands of the Americans or, above all, the Asians' (Belgian Official, 2013). Promoting good governance in zones of weak statehood was seen as a way to achieve this aim (Commission Official, 2013b). The Conflict Minerals Regulation was seen as part of a larger resource governance package that would also include the Accounting and Transparency directives (Belgian Official, 2013; Member of European Parliament, 2013). This logic was also an important motivation for investing in local certification schemes as different European companies were already doing at that time. Among the EU member states, the Netherlands, in particular, had worked with companies on certification systems. This was not only for corporate social responsibility motives but also as a long-term investment in order to have a foot on the ground if the security situation improved one day (Belgian Official, 2013; Dutch Official, 2013).

Besides these economic motives, the 2010 adoption of Section 1502 the US Dodd-Frank Wall Street Reform and Consumer Protection Act ('Dodd-Frank Act') generated an important stimulus through a socalled 'California effect' (Vogel, 1997), as Partzsch and Vlaskamp (2016: 983) explain. As part of this broader act, which was adopted as a reaction to the 2008 global financial crisis, a 'rider' was included, which made it mandatory for all Securities and Exchange Commission (SEC)-registered companies to file a report about the supply chain if they used 3TG from the Great Lakes Region (US Congress, 2010). All interviewees agreed this policy was a massive game-changer in the area of conflict minerals as it was the first legally binding supply chain due diligence requirement in a major market (Commission Official, 2013b; EEAS Official, 2013). There was no official ban on conflict minerals but all affected companies had to report whether they could assure that their product is 'DRC conflict free', which meant that it 'does not contain conflict minerals that directly or indirectly finance or benefit armed groups in the Democratic Republic of the Congo or an adjoining country' (US Congress, 2010). To sell products with 3TG to the large US market, external suppliers had to find ways to comply with their standards. According to 
estimations of the European Commission, between 150,000 and 200,000 European companies were affected by the US Dodd-Frank Act, which meant that up to 30 per cent of EU companies working with 3TG had to be cognisant of these measures (European Commission, 2014a: 24). As a consequence, European industry actors asked the Commission for assistance as they feared US companies might 'seek and switch to other suppliers that are better able to trace back the source of the minerals used' (European Commission, 2014a: 24).

\section{THE IDEATIONAL REASONING FOR THE CHOICE OF SUPPLY CHAIN DUE DILIGENCE} REQUIREMENTS

As explained in the previous section, the EU had both political and economic reasons to seek policies that would stop the trade in conflict resources from the DRC and other places. In this section I discuss why supply chain due diligence requirements were seen as the best way to achieve these objectives.

First, the 'traditional' approach of import sanction has severe enforcement problems. Even in stable regions in Africa and Asia, many natural resources are sold illegally. Some estimations say that illegal exports from these regions may amount to as much as 50 per cent of legal exports because of rampant corruption and weak government structures (Vézina, 2014). In conflict-affected and high-risk areas, the situation is usually even worse and criminal smuggling networks are thriving. The state is often unable to control any sanctions if it is not a targeted party itself, and neighbouring countries may turn a blind eye to benefit economically from sanction busting. For example, after the US House of Representatives banned DRC tantalum sales in September 2001, neighbouring Rwanda experienced a suspicious increase in tantalum exports. According to estimations, half of Rwanda's tantalum exports at that time were originally from the DRC (Nest, 2011: 26).

As a reaction to this situation, different state and non-state actors have identified transparency as a possible solution. By making clear the entire supply chain of a product, it should be easier to find the violators of these sanctions. In the area of conflict resources, the first example of this policy was the Kimberley Process, which was started by the industry and producing states in 2000 as a reaction to reports from advocacy NGOs and a UN expert commission about the limited impact of UN sanctions against 'blood diamonds' from Angola and Sierra Leone (Smillie, 2014: 70ff). The KPCS, which was implemented 2003, is an import and export scheme for rough diamonds and permits all participating states to trace gems' origins. Participating states are not allowed to trade 'conflict diamonds', as defined by the KPCS, and can 
only trade with other states that form a part of this scheme. According to its supporters, the scheme managed to reduce the global share of 'conflict diamonds' from over 15 per cent to below one per cent ${ }^{7}$. These supposed initial successes of the KPCS in regulating the flow of rough diamonds strengthened the idea that the best way to tackle the issue of conflict resources is to stimulate binding transparency measures (Partzsch and Vlaskamp, 2016: 982; Seay, 2012). The EU participated almost from the beginning in the Kimberley Process and is represented by the European Commission as it is interpreted as a matter of international trade (Vlaskamp, 2013). In 2018 (for the second time after 2007), the EU holds the chairmanship. In this function, it seeks to push a reform agenda that addresses concerns about the decreasing credibility of the KPCS as it only excludes diamonds that have funded rebel organizations, but does not deal with other socio-economic issues, such as violence committed by the state or the exploitation of miners (Mogherini, 2018). While the KPCS suffers today from these credibility problems, it played an important role in establishing the idea that tracing back the entire supply chain of a commodity can help end conflict.

Besides participating in the Kimberley Process, the EU had already supported and adopted other policies that promoted transparency in the resource sector before the Conflict Minerals Regulation. In the 2008 Raw Materials Initiative, the European Commission declared that it was 'committed to supporting respect for international corporate social responsibility instruments and [would] continue to support international initiatives to promote transparency in the extractive sector such as the Kimberly [sic] Process Certification Scheme and Extractive Industry Transparency Initiative (EITI)', which deals with corruption in the extractive industry (European Commission, 2008: 6). Another example of this belief in transparency as a 'force for good' is the 2010 EU Timber Regulation, a part of EU-FLEGT (Forest Law Enforcement, Governance, and Trade), with which the EU obliges all importers of timber and timber products to the single market to prove they have carried out due diligence to ensure their goods are legally produced (European Parliament and Council of the EU, 2010). The 2013 Accounting and Transparency Directives require extractive and logging companies to publish details of the payment they make to governments for access to natural resources in an effort to curb corruption in these places (Council of the EU, 2013b, 2013c) In sum, the Conflict Minerals Regulation was not an isolated policy but part of a broader wave of EU and international policies to stimulate transparency as a way of improving resource governance.

\footnotetext{
${ }^{7}$ It is, however, worth mentioning that the civil wars in Sierra Leone, Angola, and the DRC had already ended before the KPCS was implemented.
} 
It is important to mention that many supply chain due diligence policies, such as the US Dodd-Frank Act, do not even ban the import of natural resources produced under socially or environmentally questionable circumstances. The idea is that companies would avoid these natural resources because of possible consumer backlash. This is part of a broader belief by (Western) policymakers that transparency measures can not only be used to identify illegal behaviour but also as a tool to allow fully informed consumers to make rational decisions about the products they purchase. The idea is that consumers care about the conditions in which their purchases have been produced (Bartley, 2007: 307). In other words, if they can choose between one product that is, for example, 'conflict-free' and another whose origins are less clear, they will go for the first, thus making it attractive for companies to comply with certain standards to avoid possible consumer backlash or reputational damage. In most cases of supply chain due diligence requirements, public and/or private certifications can be used to show that a company has complied with these standards. In this context, 'consumers' does not only mean shoppers in the grocery store but also major retailers or even state institutions. As state institutions are, in most Western countries, major consumers, requiring certain social or environmental standards in public tenders can create strong economic incentives for economies to comply with them. In the United States, for example, Massachusetts reviewed its public procurement policies to ensure the Bay State's electronic and information technology suppliers did not provide products that contain conflict minerals from the DRC (Commonwealth of Massachusetts, 2017).

Besides curtailing the trade in conflict resources and, therefore, contributing to an end of the war, supply chain due diligence requirements are also expected to kick off a series of other positive developments in the targeted places as Beevers (2016) explains. First, such measures could create more broad awareness among policymakers and consumers about the social and environmental conditions under which natural resources are produced abroad. Second, the improved traceability of supply chains is expected to spill over to other dimensions of the production process. The EU aims at such an effect with the EU Timber Regulation, which focuses on the legality of imported timber. Legal behaviour is not, by definition, legitimate: some illegal raw materials are extracted under better social or environmental conditions than their legal equivalents (EEAS Official, 2013). However, the hope is that many importers will rely on more ambitious established sustainability certifications, such as the FSC or PEFC labels, as proof of compliance with the EU Timber Regulation (Commission Official, 2013a). In other words, once importers have to scrutinise their supply chain anyway for potential conflict resources, they may also evaluate it considering other socially and environmentally questionable practices. Third, through stimulating traceability 
mechanisms, the resource policy in the countries of origin would become more formalised. Companies may require, for example, state documents for their certifications. This formalisation of the extractive industry could increase state tax revenue (see, for example, in the case of the KPCS). While there is no guarantee the state will use its new revenues in the population's best interests, at least this possibility exists.

In conclusion, owing to the broad 'causal belief' that more transparency would improve resource governance, almost all stakeholders (including NGOs and industry) shared the idea that, in principle, a policy based on this idea would also be the appropriate approach for conflict resources (Commission Official, 2013b; EEAS Official b, 2013). However, as the next section will illustrate, until the adoption of the Conflict Minerals Regulation, there had to be fought several political battles between the EU institutions and other stakeholders.

\section{INSTITUTIONAL PROCESS}

Since the beginning of the 2000s, the issue of conflict minerals from the eastern DRC was already on the international agenda. A 2001 report by the Panel of Experts on the Illegal Exploitation of Natural Resources and Other Forms of Wealth of RD Congo concluded that 'illegal exploitation of the mineral and forest resources of the Democratic Republic of the Congo is taking place at an alarming rate. Two phases can be distinguished: mass-scale looting and the systematic and systemic exploitation of natural resources' (UNSC, 2001: 3). Numerous UNSC resolutions condemned this situation but did not take much action except a 2004 arms embargo. UN expert groups collected evidence that showed that almost all warring parties and their foreign sponsors were involved in looting the DRC's resources. In 2007, they recommended that 'companies which cannot demonstrate adequate due diligence practices [should] be sanctioned' (UNSC, 2007: 29). The Congolese Ministry of Mining had signed off a plan for a national certification system that year, and, according to the expert group, the UN should provide the DRC with 'technical, administrative, and financial support' for this plan (UNSC, 2007: 22). However, the UNSC ignored this advice, according to Carisch and Rickard-Martin, because several of the main industrialised states did not want to put their resource supply from that region in peril (Carisch and Rickard-Martin, 2015: 1006). Since UNSCR 1857 (2008), actors can be added to the list who are 'supporting individuals or entities, including armed groups [or criminal networks], involved in destabilizing activities in the DRC through [the] illicit [exploitation or] trade of natural resources, including gold or wildlife as well as 
wildlife products' (UNSC 1857 \& UNSCR 2293) ${ }^{8}$. While this is a potentially powerful tool, no actor has been added to a sanctions list exclusively on the basis of this resolution ${ }^{9}$.

Based on this situation at the United Nations and increasing pressure from NGOs concerning using 'conflict minerals' in consumer goods, the Organization for Economic Co-operation and Development (OECD) brought states, businesses, and NGOs together to work on a non-binding OECD Due Diligence Guidance for Responsible Supply Chain Management of Minerals from Conflict-Affected and High-Risk Areas ('OECD DDG'), which provides detailed instructions as to how an extraction company is expected to operate under these conditions (OECD, 2017). The EU participated actively in these discussions that led, in 2011, to the first version of a five-step risk-based due diligence procedure ${ }^{10}$ (OECD, 2017: 17ff). The same year, the UN also published the UN Guiding Principles on Business and Human Rights, which deal with similar issues.

While the idea of supply chain due diligence requirements for conflict resources had already been circulating in Brussels before 2010, the US Dodd-Frank Act was, nevertheless, an enormous gamechanger (Belgian Official, 2013; EEAS Official b, 2013). With the Dodd-Frank Act in their hand, NGOs and MEPs could say that if the EU was truly serious about tackling the link between natural resources and armed conflicts, it would have to emulate the example. In other words, they could exert some moral pressure on the EU to live up to its self-image of a normative power (Manners, 2008). In 2010, the UNSC endorsed the development of guidelines for appropriate due diligence for minerals from the DRC (UNSC, 2010). As an interviewed Commission Official explained, 'the EU had to do something since they had already signed all these OECD and UN documents' (Commission Official, 2013b).

As a reaction to these events, the European Parliament called in 2010 and 2011 (twice) for 'a legislative initiative along the lines (of the Dodd-Frank Act)' (European Parliament, 2010). However, it was not until March 2014 that the Commission published a draft proposal. Meanwhile, some negative side effects of the Dodd-Frank Act had been reported. Out of fear of negative publicity and because of the additional bureaucracy, many smelters and companies had decided not to import any more minerals from the DRC, leading to quasi-sanctions (Radley and Vogel, 2015; Seay, 2012). Whereas some private and public-

\footnotetext{
${ }^{8}$ The parts between the commas were added in UNSCR 2293 (2016).

${ }^{9}$ Three companies have been included in the sanctions list for violating an arms embargo by trading weapons for gold with a number of armed groups (Congomet Trading House, Machanga Ltd and Uganda Commercial Impex (UCI) Ltd).

${ }^{10}$ The current 2016 version is already the third version of the OECD DDG.
} 
private certification schemes had been designed as an answer to this legislation, their diffusion was still limited (Radley and Vogel, 2015). For Western companies, there was only a limited immediate economic incentive to set up these schemes, as it was cheaper to buy these resources from other, less fragile and more reliable places (Dutch Official, 2013). Another problem was that these systems operated in a quasimonopoly situation as they were the only legal road to sell minerals and, therefore, offered prices below those of the world market. Local miners were often in a difficult situation: either they would sell to these legal actors for below market prices or they had to turn to the illegal market, which did not offer good prices either (Radley and Vogel, 2015). Tens of thousands of local miners lost their livelihood and some joined armed groups. Instead of decreasing violence, the policy moved it to other places or even increased it (Parker and Vadheim, 2017; Radley and Vogel, 2015). In an open letter, 72 Congo experts warned the European Commission that the 'conflict minerals movement has yet to lead to meaningful improvement on the ground, and has had a number of unintended and damaging consequences' and called for 'a more nuanced and holistic approach that takes into account the realities of the eastern DRC's mining sector and the complexity of the conflict' (72 Congo Experts, 2014). As in other cases of sanctions, the EU was in a situation in which the adoption of policies to promote its norms and ideas could cause consequences that sabotage other (humanitarian) concerns (Saltnes, 2017). Because of these experiences, the Commission did not want to prohibit the import of minerals outright but looked for a more subtle approach with due diligence requirements (EEAS Official b, 2013; Member of European Parliament, 2013).

The Commission waited for some time with their first proposal, because it first wanted to see how the SEC would fill in the rather broad stipulations of the Dodd-Frank Act. The aim was to avoid double standards and ensure compliance with future EU standards would also imply compliance with US standards (Commission Official, 2013b). In 2012, the SEC decided that the OECD DDG could be used to comply with the reporting requirements of the Dodd-Frank Act (OECD, 2017). Subsequently, the OECD DDG became the standard for all policies in this area. It has not only been used for the EU Conflict Minerals Regulation, but also for a Canadian draft regulation on conflict minerals, for DRC law, for the International Conference on the Great Lakes Region's Mineral Tracking and Certification Scheme and for official guidelines in Australia, China, Turkey, and the United Arab Emirates (Partzsch and Vlaskamp, 2016: 980).

While the Commission was waiting on the decisions of the SEC, there was also a time-pressure element, because proponents of a policy wanted a first draft before the 2014 European Parliament elections. Trade commissioner Karel de Gucht, a Belgian national, had shown great interest in the situation in the former 
Belgian colony and was a strong supporter of a Conflict Minerals Regulation. The fear by NGOs and proregulation MEPs was that another trade commissioner would give this issue less importance and that it would disappear again from the agenda (NGO Representative, 2013). From 27 March 2013 to 26 June 2013, a public consultation process was run.

The Commission's draft was close to the positions of the business groups (European Commission, 2014b). In the public consultation process, many companies had expressed their interest in some regulation for the abovementioned economic motivations, but supported in the first place political and financial support for existing certification systems while warning against additional red tape and administrative costs. According to the Commission's proposal, the EU would set up a voluntary self-certification due diligence system for importers of $3 \mathrm{TG}$ from conflict regions to the EU. Importers could choose to be included in a list of 'responsible importers', which implied they had complied with the standards set by the OECD DDG and which could, for example, become a requirement for participation in public tenders (European Commission, 2014b). Several interviewees called this an 'American' solution to the issue because of its trust in the market as a regulating force (Belgian Official, 2013). In sum, those companies that needed certification for compliance with the Dodd-Frank Act could opt-in, whereas the rest of the European companies would not have to carry possible added costs if they did not want to. By using 'carrots' instead of 'sticks', this proposal sought to avoid the 'quasi-sanction'-effect the Dodd-Frank Act had caused.

The NGOs and pro-binding regulation parts of the European Parliament did not place much trust in this consumer-driven approach and feared that few companies would ask for this certification (Barbière, 2015). They saw this draft as much less ambitious as the US Dodd-Frank Act and feared that only those companies would comply with it that had no other option. In the opinion of an interviewed MEP, policies concerning social or environmental standards usually undergo a three-step process: 'First, the industry denies that there is a problem. Then they recognise it but say that they can fix it themselves. And in the end, the state concludes that it is better to impose some legislation' (Member of European Parliament, 2013). Therefore, their interpretation of supply chain due diligence measures was that all companies needed to be legally obliged to provide transparency about the origins of their products in order to mitigate possible risks. The choice between voluntary and binding measures became the main point of discussion in the debates. The Commission's Impact Assessment had estimated that mandatory reporting obligations, following the OECD DDG, would cost $€ 8.4$ billion initially, and approximately $€ 1.7$ billion on a recurrent annual basis thereafter (European Commission, 2014a: 56). Business groups, such as the French Medef lobbied against binding regulations and warned MEPs individually that such measures would cause 'very 
significant costs, particularly for small businesses: disproportionate compared to the expected results' (Barbière, 2015).

In May 2015, the European Parliament supported, somewhat surprisingly, with the votes of the left parties, last-minute amendments calling for compulsory ethical sourcing (European Parliament, 2015). As these results were stricter than the outcomes of the working group negotiations, and following a rather unusual procedure, Parliament decided to enter the trilateral negotiations with the EU Council and Commission before making their formal decisions in the first reading. MEPs were already aware of the fact that these proposals would probably go too far for many member states, such as Germany, which was critical of some stipulations because of the possible financial implications for its automotive industry (Belgian Official, 2013).

The final Conflict Minerals Regulation seeks to bring all sides together by including legally binding and consumer-driven voluntary elements (Council of the EU, 2017b). Somewhat ironic, only one month earlier, the SEC declared that it would not enforce section 1502 of the US Dodd-Frank Act until further notice owing to a court decision. The US Court of Appeals in the District of Columbia had ruled that the provisions were in violation of the $1^{\text {st }}$ amendment of the US Constitution. To make it mandatory for companies to publish information about themselves that could be against their own interests (saying their product was not DRC conflict-free) was deemed an infringement to the right of free speech (SEC, 2017). According to the EU Conflict Minerals Regulation, importers of mineral ores, concentrates, or processed metals of 3TG are legally required to perform due diligence. This means all EU upstream companies (mining companies, raw material traders, smelters and refiners) will be subject to the regulation. The scope is, however, indirectly not limited to the EU. Importers are expected to buy their goods from 'responsible sources', which comply with the OECD DDG. The EU Commission plans to publish a 'white list' of global smelters and refiners who qualify for this classification. According to Commission estimates, these provisions will, directly and indirectly, affect about 500 smelters and refiners, inside and outside the EU (European Commission, 2017). The hope is that all major global smelters want to be included in the 'white list' and there will no longer be any smelters for conflict resources, making them worthless.

EU downstream companies (traders, producers, manufacturers, end users, etc.) are only subject to this legislation if they import 3TG in the metal stage. This is a significant difference from the Dodd-Frank Act, which also covers manufactured products. In other words, if 3TG is already part of an imported component or product (e.g. a cell phone or computer chip) it is not subject to the Conflict Minerals 
Regulation. NGOs have criticised this element as a major loophole in the regulation (Global Witness, 2016). Smaller importers (such as jewellers and dentists) are excluded from the obligation to file a report about their due diligence practices. Altogether, according to the Commission, between 600 and 1,000 EU importers will be affected by this regulation (European Commission, 2017).

Further, companies subject to the EU directive on non-financial reporting (with more than 500 employees) are expected to explain how they plan to monitor the source of minerals used in their products. This is a more consumer-driven incentive, as the EU hopes these companies will seek ways to demonstrate they are doing everything they can to not use conflict resources. Another difference with the Dodd-Frank Act is the broader geographical scope, which is not limited to the African Great Lakes region. Instead, the Commission will ask external experts to develop a list of conflict-affected and high-risk areas, which will be regularly updated. The Conflict Minerals Regulation is limited in scope to 3TG but has been deliberately left open for additions. Some NGO campaigns tried to seize the opportunity and promoted even broader regulations than the US Dodd-Frank Act, which would allow 'other natural resources linked to conflict and human rights abuses_-such as diamonds, jade and coal— to be added in the future' (Global Witness, 2015). The fact that the Conflict Minerals Regulation left this option open was positively interpreted by them (Global Witness, 2016). Companies have time to adapt their supply chain policies as the Conflict Minerals Regulation will only come into force in 2021.

In conclusion, and referring to the analytical framework, institutional factors played an important role in the practical implementation of the supply chain due diligence requirements. While there was a consensus on the interests and ideas at stake, the nuts and bolts of the EU Conflict Minerals Regulation were the result of compromises between the involved parties. For NGOs and most of the European Parliament, the final outcome was less ambitious than they had hoped for. Partzsch talks about 'symbolic normative power' in the sense that the EU based this policy on shared norms, but EU member states 'have either been incapable or unwilling to regulate the practices of their domestic minerals industry and processing businesses in conflict regions' (Partzsch, 2018: 8). For NGOs and most of the European Parliament, the final outcome was less ambitious than they had hoped, but there were some legally binding elements that would potentially affect all major smelters, and the possibility to use this regulation as a door opener for broader regulations in the future. The more business-friendly actors (e.g. Commission, business groups, some Member States) could not stop all binding measures but their scope was more limited than in the case of the US policy. 


\section{CONCLUSION}

Curtailing the trade in conflict resources is a part of the EU's approach to many conflicts. With the Conflict Minerals Regulation, the EU is using supply chain due diligence requirements for the first time, with the exception of the EU Timber Regulation, to achieve this objective. The principal aim of this article has been to explain why the EU is choosing these policies to dry up the funding of armed conflict by natural resources. To do so, it has used Hyde-Price's analytical framework, which includes the EU's interests, ideas, and institutions. To answer the initial question concisely: the EU adopted these measures for potential conflict resources because it thought stimulating transparency in global supply chains was the best way to achieve its political and economic objectives.

In terms of interests, these policy measures have been motivated by a number of factors. Improving the security situation in the DRC is a long-standing EU policy objective. Besides humanitarian reasons, this aim is also driven by the country's natural resources. Once the situation becomes less violent, EU companies can gain more stable access to the DRC's commodities. Another economic interest was conditioned by the US Dodd-Frank Act. As a result of this legislation, EU companies that exported to the United States had to provide information whether their shipment could potentially contain 'conflict minerals'. To not lose clients in the United States, European companies asked for policies that would help them to comply with these requirements.

The next step of the analysis was to see why the EU had the idea that supply chain due diligence requirements was the best policy in light of their interests. The main explanation is the 'causal belief' that transparency would, directly and indirectly, contribute to achieving these objectives. Existing sanctions regimes often lack effectiveness because of the problems of limited statehood in the targeted regions. Already prior to the Conflict Minerals Regulation, the EU had placed trust in transparency as a force for good in the resource sector, such as for ending the trade in 'blood diamonds' (Kimberley Process), illegally logged timber (EU Timber Regulation), or corruption (Accounting and Transparency Directives). However, it was external events that created more urgency for the EU to develop a specific policy concerning conflict minerals. The Kimberley Process established the idea that supply chain due diligence measures for conflict resources would be a good idea, the OECD DDG set a global standard for responsible sourcing in conflict zones, and the US Dodd-Frank created both political and economic pressure on the EU to adopt legally binding policies. 
The third part of the framework, institutions, explained why it took the EU some time to reach the final EU Conflict Minerals Regulation. While the belief in transparency measures as an appropriate tool was widely shared, the concrete content of the EU Conflict Minerals Regulation was the subject of intense discussions between the different stakeholders. Commission, Council, and industry wanted to keep the obligation to be transparent as voluntary as possible for the high costs of these policies while Parliament and activist NGOs worked for binding measures. The final policy design is a compromise between these positions.

\section{References}

Open Letter.

Available at: https://ethuin.files.wordpress.com/2014/10/09092014-open-letter-final-and-list-doc.pdf (accessed 11 April 2017).

Arnould V and Vlassenroot K (2016) EU Policies in the Democratic Republic of Congo: Try and Fail? Egmont Institute. Available at: http://www.egmontinstitute.be/eu-policies-in-the-democraticrepublic-of-congo-try-and-fail/ (accessed 12 March 2018).

Barbière C (2015) Parliament votes for tougher conflict minerals regulation. Euractiv, 21 May. Available at: https://www.euractiv.com/section/development-policy/news/parliament-votes-for-tougherconflict-minerals-regulation/ (accessed 12 March 2018).

Bartley T (2007) Institutional Emergence in an Era of Globalization: The Rise of Transnational Private Regulation of Labor and Environmental Conditions. American Journal of Sociology 113(2): 297351.

Beevers MD (2016) U.S Domestic Regulation of Global Conflict Resources. Orbis 60(1): 87-111.

Belgian Official (2013) Interview in Brussels.

Biersteker T and Portela C (2015) EU Sanctions in Context: Three Types. Research Collection School of Social Sciences $1688 . \quad$ Available at: http://ink.library.smu.edu.sg/cgi/viewcontent.cgi?article=2941\&context=soss_research (accessed 11 April 2017).

Carisch E and Rickard-Martin L (2015) UN Natural Resources and Other Sanctions: Who Benefits? Social Research: An International Quarterly 82(4): 983-1014.

Commission Official (2013a) Interview in Brussels (DG Environment).

Commission Official (2013b) Interview in Brussels (FPI). 
Commonwealth of Massachusetts (2017) Resolve Examining Commonwealth Procurement Policies Relative to Congo Conflict Minerals. Available at: https://malegislature.gov/Laws/SessionLaws/Resolves/2016/Chapter5.

Council of the EU (2003) A Secure Europe in a better World: European Security Strategy. Available at: http://www.consilium.europa.eu/uedocs/cmsUpload/78367.pdf (accessed 3 May 2011).

Council of the EU (2008) Report on the Implementation of the European Security Strategy: Providing Security in a Changing World. European Council. Available at: http://www.consilium.europa.eu/uedocs/cms_data/docs/pressdata/en/reports/104630.pdf (accessed 3 May 2017).

Council of the EU (2011) Council Regulation (EU) No 25/2011 of 14 January 2011 amending Regulation (EC) No 560/2005 imposing certain specific restrictive measures directed against certain persons and entities in view of the situation in Côte d'Ivoire. Available at: http://eurlex.europa.eu/LexUriServ/LexUriServ.do?uri=OJ:L:2011:011:0001:0017:EN:PDF (accessed 11 April 2017).

Council of the EU (2012) Council Regulation (EU) No 36/2012 of 18 January 2012 concerning restrictive measures in view of the situation in Syria and repealing Regulation (EU) No 442/2011. Available at: http://eur-lex.europa.eu/LexUriServ/LexUriServ.do?uri=OJ:L:2012:016:0001:0032:EN:PDF (accessed 11 April 2017).

Council of the EU (2013a) Council Regulation (EU) No 697/2013 of 22 July 2013 amending Regulation (EU) No 36/2012 concerning restrictive measures in view of the situation in Syria. Available at: http://eur-lex.europa.eu/LexUriServ/LexUriServ.do?uri=OJ:L:2013:198:0028:0034:EN:PDF (accessed 11 April 2017).

Council of the EU (2013b) Directive 2013/34/EU of the European Parliament and of the Council of 26 June 2013 on the annual financial statements, consolidated financial statements and related reports of certain types of undertakings, amending Directive 2006/43/EC of the European Parliament and of the Council and repealing Council Directives 78/660/EEC and 83/349/EEC Text with EEA relevance. Available at: http://eur-lex.europa.eu/legalcontent/EN/TXT/?uri=celex\%3A32013L0034 (accessed 12 March 2018).

Council of the EU (2013c) Directive 2013/50/EU of the European Parliament and of the Council of 22 October 2013 amending Directive 2004/109/EC of the European Parliament and of the Council on the harmonisation of transparency requirements in relation to information about issuers whose securities are admitted to trading on a regulated market, Directive 2003/71/EC of the European Parliament and of the Council on the prospectus to be published when securities are offered to the public or admitted to trading and Commission Directive 2007/14/EC laying down detailed rules for the implementation of certain provisions of Directive 2004/109/EC Text with EEA relevance. Available at: http://eur-lex.europa.eu/legal-content/EN/ALL/?uri=celex:32013L0050 (accessed 9 March 2018).

Council of the EU (2017a) Council Decision (CFSP) 2017/1385 of 25 July 2017 amending Decision (CFSP) 2015/778 on a European Union military operation in the Southern Central Mediterranean (EUNAVFOR MED operation SOPHIA). Available at: 
https://eeas.europa.eu/sites/eeas/files/eu_council_decision_1385_17_op_sophia_extension_until_ 31_12_2018.pdf (accessed 24 October 2017).

Council of the EU (2017b) Regulation of the European Parliament and of the Council setting up a Union system for supply chain due diligence self-certification of responsible importers of tin, tantalum and tungsten, their ores, and gold originating in conflict-affected and high-risk areas. Available at: http://data.consilium.europa.eu/doc/document/ST-7239-2017-INIT/en/pdf (accessed 6 April 2017).

Diez T (2014) Setting the limits: Discourse and EU foreign policy. Cooperation and Conflict 49(3): 319333.

Dutch Official (2013) Interview in The Hague.

EEAS Official (2013) Interview in Brussels.

EEAS Official b (2013) Interview in Brussels.

EU Official (2015) E-Mail Exchange.

European Commission (2008) Communication from the Commission to the European Parliament and the Council - The raw materials initiative : meeting our critical needs for growth and jobs in Europe. Available at: http://eur-lex.europa.eu/legalcontent/EN/TXT/PDF/?uri=CELEX:52008DC0699\&from=EN (accessed 2 May 2017).

European Commission (2011) Tackling the Challenges in Commodity Markets and on Raw Materials. $\operatorname{COM}(2011) \quad 25$ final, 2 February. Available at: http://eurlex.europa.eu/LexUriServ/LexUriServ.do?uri=COM:2011:0025:FIN:en:PDF （accessed 2 September 2014).

European Commission (2014a) Commission Staff Working Document - Impact Assessment Accompanying the document 'Proposal for a Regulation of the European Parliament and of the Council setting up a Union system for supply chain due diligence self-certification of responsible importers of tin, tantalum and tungsten, their ores, and gold originating in conflict-affected and high-risk areas'. Available at: http://trade.ec.europa.eu/doclib/docs/2014/march/tradoc_152229.pdf (accessed 11 April 2017).

European Commission (2014b) Proposal for a Regulation of the European Parliament and of the Council setting up a Union system for supply chain due diligence self-certification of responsible importers of tin, tantalum and tungsten, their ores, and gold originating in conflict-affected and high-risk areas. Available at: http://trade.ec.europa.eu/doclib/docs/2014/march/tradoc_152227.pdf (accessed 11 April 2017).

European Commission (2017) The regulation explained. Available at: http://ec.europa.eu/trade/policy/infocus/conflict-minerals-regulation/regulation-explained/ (accessed 5 May 2017). 
European Council (2001) EU Programme for the Prevention of Violent Conflicts. Available at: http://www.eplo.org/assets/files/3.\%20Resources/EU\%20Documents/EU_EU_Programme_for_t he_Prevention_of_Violent_Conflicts.pdf (accessed 29 July 2011).

European Parliament (2010) European Parliament resolution of 7 October 2010 on failures in protection of human rights and justice in the Democratic Republic of Congo. Available at: http://www.europarl.europa.eu/sides/getDoc.do?type=TA\&reference=P7-TA-20100350\&language $=\mathrm{EN}$ (accessed 15 March 2017).

European Parliament (2015) Amendments adopted by the European Parliament on 20 May 2015 on the proposal for a regulation of the European Parliament and of the Council setting up a Union system for supply chain due diligence self-certification of responsible importers of tin, tantalum and tungsten, their ores, and gold originating in conflict-affected and high-risk areas. Available at: http://www.europarl.europa.eu/sides/getDoc.do?pubRef=-//EP//TEXT+TA+P8-TA-20150204+0+DOC+XML+V0//EN (accessed 11 April 2017).

European Parliament and Council of the EU (2010) Regulation No 995/2010 of 20 October 2010 laying down the obligations of operators who place timber and timber products on the market. Available at: http://eur-lex.europa.eu/LexUriServ/LexUriServ.do?uri=OJ:L:2010:295:0023:0034:EN:PDF (accessed 5 May 2017).

European Union (2016) Shared Vision, Common Action: A Stronger Europe (A Global Strategy for the European Union's Foreign And Security Policy). Available at: https://eeas.europa.eu/top_stories/pdf/eugs_review_web.pdf (accessed 3 October 2016).

Giumelli F (2011) Coercing, Constraining and Signaling: Explaining UN and EU Sanctions After the Cold War. Colchester: ECPR Press.

Global Witness (2006) The Sinews of War: Eliminating the Trade in Conflict Resources. Available at: https://www.globalwitness.org/sites/default/files/import/the_sinews_of_war.pdf (accessed 12 April 2017).

Global Witness (2015) Advising Policy Makers. Available at: https://www.globalwitness.org/en/campaigns/conflict-minerals/advising-policy-makers/ (accessed 14 April 2017).

Global Witness (2016) EU: Conflict Minerals agreement reached as exemptions added. Available at: https:/www.globalwitness.org/en/campaigns/conflict-minerals/eu-conflict-minerals-agreementreached-exemptions-added/ (accessed 17 April 2017).

Goldstein J and Keohane RO (1993) Ideas and Foreign Policy: Beliefs, Institutions, and Political Change. Cornell University Press.

Hyde-Price A (2004) Interests, institutions, and identities in the study of European foreign policy. In: Christiansen, T. and Tonra, B. (eds) Rethinking European Union Foreign Policy. Manchester: Manchester University Press, pp. 99-113. 
Jones L (2015) Societies Under Siege: Exploring How International Economic Sanctions (Do Not) Work. Oxford \& New York: Oxford University Press.

Knutsen BO (2009) The EU's Security and Defense Policy (ESDP) and the Challenges of Civil-Military Coordination (CMCO): The Case of the Democratic Republic of Congo (DRC). European Security 18(3): 451-459.

Krahmann E (2003) Multilevel Networks in European Foreign Policy. Aldershot \& Burlington: Ashgate Publishing Limited.

Le Billon P (2012) Wars of Plunder: Conflicts, Profits and the Politics of Resources. London: C. Hurst \& Co.

Manners I (2008) The normative ethics of the European Union. International Affairs 84(1): 45-60.

Member of European Parliament (2013) Interview in Brussels.

Mogherini F (2018) Parliamentary Questions: Answer given by Vice-President Mogherini on behalf of the Commission. Available at: http://www.europarl.europa.eu/sides/getAllAnswers.do?reference=P-2018$001463 \&$ language $=\mathrm{EN}$ (accessed 19 July 2018).

Nest M (2011) Coltan. Cambridge \& Malden (MA): Polity Press.

NGO Representative (2013) Interview in The Hague.

OECD (2017) OECD Due Diligence Guidance for Responsible Supply Chains of Minerals from ConflictAffected and High-Risk Areas. Available at: http://www.oecd.org/corporate/mne/mining.htm (accessed 10 February 2017).

Parker DP and Vadheim B (2017) Resource Curse or Policy Cursed? U.S. Regulation of Conflict Minerals and Violence in the Congo. Journal of the Association of Environmental and Resource Economists 4(1): 1-49.

Partzsch L (2018) The new EU Conflict Minerals Regulation: Normative Power in International Relations? Global Policy. Available at: https://onlinelibrary.wiley.com/doi/epdf/10.1111/17585899.12575 (accessed 31 August 2018).

Partzsch L and Vlaskamp MC (2016) Mandatory due diligence for 'conflict minerals' and illegally logged timber: Emergence and cascade of a new norm on foreign accountability. The Extractive Industry and Society 3(4): 978-986.

Portela C (2005) Where and why does the EU impose sanctions? Politique Européenne 18(3): 83-111.

Portela C (2011) European Union Sanctions and Foreign Policy: When and Why Do They Work? London $\&$ New York: Routledge. 
Radley B and Vogel C (2015) Fighting windmills in Eastern Congo? The ambigious impact of the 'conflict minerals' movement. The Extractive Industry and Society 2(3): 406-410.

Saltnes JD (2017) Norm collision in the European Union's external policies: The case of European Union sanctions towards Rwanda. Cooperation and Conflict 52(4): 553- 570.

Seay LE (2012) What's Wrong with Dodd-Frank 1502? Conflict Minerals, Civilian Livelihoods, and the Unintended Consequences of Western Advocacy. Center for Global Development Working Paper 284.

SEC (2017) Updated Statement on the Effect of the Court of Appeals Decision on the Conflict Minerals Rule. Available at: https://www.sec.gov/news/public-statement/corpfin-updated-statement-courtdecision-conflict-minerals-rule.

Smillie I (2014) Diamonds. Cambridge \& Malden: Polity Press.

Smis S and Kingah SS (2009) Unassertive Interregionalism in the Great Lakes Region. In: Fredrik Söderbaum and Patrik Stålgren (eds) The European Union and the Global South. Boulder (CO) and London: Lynne Rienner, pp. 205-223.

UNSC (2001) Report of the Panel of Experts on the Illegal Exploitation of Natural Resources and Other Forms of Wealth of DR Congo. Available at: https://www.securitycouncilreport.org/atf/cf/\%7b65BFCF9B-6D27-4E9C-8CD3CF6E4FF96FF9\%7d/DRC\%20S\%202001\%20357.pdf (accessed 18 July 2018).

UNSC (2007) Report of the UN Group of Experts on the DRC. S/2007/423. Available at: http://www.un.org/ga/search/view_doc.asp?symbol=S/2007/423 (accessed 10 February 2017).

UNSC (2010) Resolution 1952 (2010) Adopted by the Security Council at its 6432nd meeting, on 29 November 2010. Available at: http://www.un.org/ga/search/view_doc.asp?symbol=S/RES/1952\%282010\%29 (accessed 20 October 2017).

UNSC (2013) Minutes: Maintenance of international peace and Security - Conflict prevention and natural resources. Available at: http://www.securitycouncilreport.org/atf/cf/\%7B65BFCF9B-6D274E9C-8CD3-CF6E4FF96FF9\%7D/s_pv_6982.pdf (accessed 2 January 2016).

US Congress (2010) Dodd-Frank Wall Street Reform and Consumer Protection Act. Available at: https://www.gpo.gov/fdsys/pkg/PLAW-111publ203/pdf/PLAW-111publ203.pdf (accessed 10 February 2017).

Vézina P-L (2014) Illegal trade in natural resources: evidence from missing exports. OxCarre Research Paper 139. Oxford: Oxford Centre for the Analysis of Resource Rich Economies. Available at: http://www.oxcarre.ox.ac.uk/files/OxCarreRP2014139.pdf (accessed 1 April 2016).

Vlaskamp MC (2013) Balancing Fundamental Rights Protection and Effective Multilateralism: The EU and Zimbabwe's Marange Diamonds. European Foreign Affairs Review 18(4/1): 529-546. 
Vogel D (1997) Trading up and governing across: transnational governance and environmental protection. Journal for European Public Policy 4(4): 556-571. 